\title{
湿地植物植硅体的生物地球化学碳汇: 以西溪湿地为例
}

李自民 ${ }^{(1)}$ ，宋照亮 ${ }^{(12)(4) *}$ ，姜培坤 ${ }^{(12)}$
(1) 浙江农林大学环境与资源学院, 临安 311300;
(2) 浙江农林大学浙江省森林生态系统碳循环与固碳减排重点实验室, 临安 311300;
(3) 中国科学院地球化学研究所, 环境地球化学国家重点实验室, 贵阳 550002;
(4) 北京大学地表过程分析与模拟教育部重点实验室, 北京 100871
*联系人, E-mail: songzhaoliang78@163.com

IPCC 曾指出大气中 $\mathrm{CO}_{2}$ 浓度的持 续升高, 可能会给全球带来一系列危 险的气候变化. 寻找一种新的有效降 低和缓解大气中 $\mathrm{CO}_{2}$ 的方法, 或许是 人类目前最紧要的任务. 植硅体态碳 (phytolith-occluded-carbon), 作为一种 长期的生物地球化学碳汇机制, 可能 在全球碳循环和气候变化中扮演着重 要的作用.

草本植物占主导地位的湿地生态 系统拥有较高的初级生产力, 了解湿 地植物植硅体固定大气中 $\mathrm{CO}_{2}$ 的潜力, 有着重要的意义. 本研究采集杭州西 溪湿地的 18 种植物, 利用 WalkleyBlack 消解和 Kroger 等人的方法, 分析 了其植硅体中碳含量的变化. 研究结 果表明, 18种植物植硅体中碳的含量 变化在 $0.49 \%$ 3.97\% 之间, 其变异系 数高达 $810 \%$; 与农作物生态系统中小 麦、乘和粟植硅体研究结果不同的是, 草本植物占主导地位的湿地生态系统 中植物植硅体态碳占干物质的百分量 不仅与植硅体中碳的百分含量有较强 的相关性 $\left(R^{2}=0.6066, P<0.01\right)$, 而且与 植硅体占干物质的百分含量有显著的 相关性 $\left(R^{2}=0.3477, P<0.05\right)$ (图1), 它表 明, 对于草本植物占主导地位的湿地 生态系统中植物植硅体态碳占干物质 的产量取决于植物植硅体占干物质量
的同时, 也需要植物在生长过程形成 的植硅体固定大气中 $\mathrm{CO}_{2}$ 的效率值.

依据 Wheeler 和 Shaw 估算的草本 植物占主导地位的湿地生态系统的初 级生产力 (1 29 $\left.\mathrm{t} \mathrm{ha}^{-1} \mathrm{a}^{-1}\right)$ 和草本植物 植硅体态碳占干物质的百分含量平均 值 $(0.072 \%)$, 估算的草本植物占主导 地位的湿地生态系统植物植硅体固定 大气中 $\mathrm{CO}_{2}$ 的通量变化范围在 $0.003 \sim$ $0.077 \mathrm{t}-\mathrm{e}-\mathrm{CO}_{2} \mathrm{ha}^{-1} \mathrm{a}^{-1}$ 之间. 中国 $1.37 \mathrm{x}$ $10^{7} \mathrm{ha}$ 的草本植物主导的湿地植物植 硅体固定大气中 $\mathrm{CO}_{2}$ 的速率为 $0.04 \times$ $10^{6} \sim 1.05 \times 10^{6} \mathrm{t} \mathrm{a}^{-1}$. 全球草本植物占主 导地位的湿地 $\left(1.48 \times 10^{8} \mathrm{ha}\right)$ 植物植硅 体以 $0.077 \mathrm{t}-\mathrm{e}-\mathrm{CO}_{2} \mathrm{ha}^{-1} \mathrm{a}^{-1}$ 最大效率值,
每年可以固定 $1.14 \times 10^{7} \mathrm{t}$ 的 $\mathrm{CO}_{2}$. 进一 步推算表明, 如果全球所有湿地植物 和草本植物占主导地位沼泽湿地生态 系统植物植硅体有同样的 $0.077 \mathrm{t}$-e$\mathrm{CO}_{2} \mathrm{ha}^{-1} \mathrm{a}^{-1}$ 最大效率值, 那么 $5.7 \times 10^{8}$ ha 的湿地植物每年固定大气中 $\mathrm{CO}_{2}$ 的 量高达 $4.39 \times 10^{7} \mathrm{t}$, 大约可以抵消 1.69 $\times 10^{7} \mathrm{t}$ 标准煤燃烧排放的 $\mathrm{CO}_{2}$.

本研究认为如果能对湿地生态植 物进行适当的管理(例如, 选择一种植 硅体含量高或植硅体固碳效率值高及 初级生产力高的植物进行种植)来增加 植硅体态碳占干物质的产量, 对增加 湿地生态系统植物植硅体固定大气中 $\mathrm{CO}_{2}$ 的潜力有重要的意义.

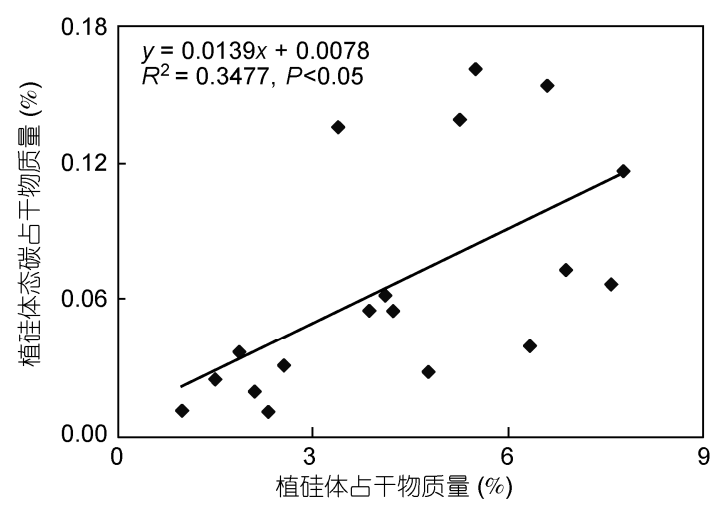

图 1 草本植物占主导地位的湿地生态系统中植物植硅体态碳占干物质百分含量 与植硅体占干物质的百分含量相关性 Sci Bull, 2013, 58, doi: 10.1007/s11434-013-5785-3 